\title{
Persepsi Masyarakat Tentang Pendidikan Menengah Di SMA Negeri 2 Kota Sorong
}

\author{
Daeng Pabalik ${ }^{1}$, Ibrahim² \\ ${ }^{1}$ Fakultas Ilmu Sosial Dan Ilmu Politik, Universitas Muhammadiyah Sorong \\ ${ }^{2}$ Fakultas Keguruan Dan Ilmu Pendidikan, Universitas Muhammadiyah Sorong
}

Email: daengpabalik@gmail.com

\begin{abstract}
ABSTRAK
Persepsi masyarakat terhadap pendidikan menengah, khususnya SMAN 2 Kota Sorong Kota Sorong sangat bervariasi. Tujuan penelitian ini ialah untuk mengetahui persepsi masyarakat tentang pendidikan menengah di Kota Sorong. Penelitian ini menggunakan pendekatan kualitatif, dan data penelitian dikumpulkan melalui beberapa cara yakni: (1) wawancara, (2) observasi, dan (3) dokumentasi. Teknik analisis data menggunakan metode analisis data kualitatif Moleong. Hasil Penelitian ini menunjukkan : Pertama, Kualitas pembelajaran dan lulusan, pola kepemimpinan, kemampuan guru, kerja sama dan keterjangkauan lokasi sekolah merupakan pembentuk persepsi masyarakat terhadap penyelenggaraan pendidikan menengah, Kedua, Makna pendidikan menengah mengarah pada kebutuhan kerja dan melanjutkan studi. Ketiga, Karakteristik pendidikan menengah adalah untuk menumbuhkan kemampuan dalam soft skills dan life skills; Keempat, Sekolah yang memiliki kondisi sosial ekonomi yang baik cenderung mendorong siswanya untuk berprestasi lebih baik. Sebaliknya, siswa cenderung berprestasi lebih rendah dari yang semestinya, bila sekolah memiliki kondisi sosial ekonomi lebih lemah; Kelima, Pendidikan masyarakat yang rendah menunjukkan kualitas sumber daya manusia yang rendah dan merugikan secara individu. Oleh karena itu, persepsi masyarakat terhadap penyelenggaraan pendidikan menengah ditentukan oleh kualitas pembelajaran, kualitas lulusan, pola kepemimpinan, kemampuan guru, kerja sama dan aksesibilitas
\end{abstract}

Kata Kunci : Persepsi, Makna, Penyelenggaraan, Pendidikan

\begin{abstract}
Community perception of Secondary Eduction, especially SMAN 2 Kota Sorong, West Papua varied widely. This research aimed to analyze the perception of community on secondary education in Sorong West Papua. This research used qualitative approach and the data collected by using in-deep interview, participants' observation, and documentation. The data were analysed used Maleong qualitative approach. Thes result of this study indicated; First, the quality of learning and graduates, leadership, teacher abilities, cooperation and affordability of school,and location were a form of public perception of the implementation of secondary education. Secondly, the meaning of secondary education leads to work needs and continuing studies. Third, the characteristic of secondary education are to foster abilities in soft skills and life skills; fourth, students have a greater chance of achievement if the school has has better socio-economic conditions. Conversely, students tend to perform lower if the school has weaker socio-economic conditions; Fifth, low community education shows the quality of human resources is low and detrimental to individuals and and the state. In this case the public perception of the implementation of secondary educationwas determined by the quality of learning, the quality of graduates, leadership, teachers ability, cooperation and and accessibility.
\end{abstract}

Keywords : Perception, Meaning, Organization, education 


\section{PENDAHULUAN}

Peningkatan kesejahteraan warga negara dalam aspek sosial, ekonomi, politik dan kultural merupakan salah satuju tujuan dari proses pembangunan yang dilakukan secara berkelanjutan. Pembangunan dalam bidang pendidikan yang strategis sangat penting untuk (Zamroni 2001 ; 2). Hal itu sesuai dengan amanat Pembukaan Undangundang Dasar Negara Republik Indonesia tahun 1945 bahwa tujuan nasional Indonesia adalah untuk melindungi segenap bangsa dan seluruh tumpah darah Indonesia, untuk memajukan kesejahteraan umum, mencerdaskan kehidupan bangsa, dan ikut melaksanakan ketertiban dunia berdasarkan kemerdekaan, perdamaian abadi, dan keadilan sosial. Dalam kerangka tersebut, pendidikan merupakan faktor yang sangat menentukan kontinuitas pembangunan bangsa Indonesia.

Peran yang pertama merupakan fungsi politik pendidikan dan dua peran yang lain merupakan fungsi ekonomi. Karena itu, pendidikan juga disebut sebagai lokomotif pembangunan sehingga mendorong pemerintah Indonesia melakukan pembenahan dan pengembangan dalam berbagai lini/sektor pendidikan.

Perubahan paradigma pembangunan fisik ke arah pembangunan pendidikan saat ini dapat dijelaskan sekurang-kurangnya dalam dua perspektif. Pertama, secara luas berdasarkan perspektif global, perubahan terjadi karena perkembangan demokrasi yang pesat. Artinya, terdongkraknya demokrasi terutama di negara-negara dunia Kesadaran ini berimplikasi pada pembangunan manusia seutuhnya, termasuk kebutuhan dasar pendidikan. Dengan kata lain, demokrasi menciptakan prakondisi ke arah kesadaran akan kebutuhan pendidikan bagi semua lapisan masyarakat. Kedua, dalam perspektif nasional perubahan dirasakan secara langsung seiring dengan kerangka peralihan pembangunan sentralistik ke desentralistik.

Seperti halnya dengan kebijakan Otonomi khusus daerah (Otsusda) di Kota Sorong Papua Barat yang diarahkan kepada pelaksanaan program-program pembangunan yang merupakan kebutuhan mendasar masyarakat. Ada empat (4) prioritas pemerintah propinsi Papua, yaitu: (1)pendidikan, terutama untuk masyarakat pedalaman dan pesisir. (2)kesehatan, dimana pemerintah menyediakan paket-paket obat khusus dengan tulisan otonomi khusus; (3)Ekonomi berbasis rakyat, (4) strategi ketahanan nasional yang diharapkan mengutamakan kesejahteraan - masyarakat Papua untuk mempertahankan Negara 
Kesatuan Republik Indonesia dan menjadi penjaga perbatasan.

Keseriusan daerah ini merupakan indikasi bahwa pembangunan pendidikan sumber daya manusia sangat penting. Dalam konteks Kota Sorong, pembangunan sumber daya manusia diarahkan kepada pemberdayaan setiap sendi kehidupan masyarakat. Pemberdayaan sumber daya manusia merupakan tanggung jawab semua pihak, baik aparat pemerintah maupun masyarakat, termasuk lembaga pendidikan. Namun persoalan yang sering muncul adalah rendahnya kesadaran masyarakat terhadap pentingnya pendidikan.

Jumlah Penduduk Kota Sorong pada tahun 2009 tercatat 172.855 jiwa. Sekitar $52 \%$ dari total penduduk adalah laki-laki, sisanya $\quad 48 \%$ perempuan.Komposisi penduduk Kota Sorong tergolong penduduk muda. Persentase penduduk pada kelompok umur muda lebih besar daripada kelompok umur tua. Pada kelompok umur 0 - 4 tahun tercatat $12,5 \%$ sedangkan pada kelompok umur 75 tahun tercatat $0,31 \%$

Tabel 1 Penduduk Kota Sorong Dan Kepadatannya Menurut Distrik Tahun 2009

\begin{tabular}{lccc}
\hline Distrik & $\begin{array}{c}\text { Luas } \\
\text { Daerah } \\
\left(\mathbf{K m}^{\mathbf{2}}\right)\end{array}$ & Penduduk & $\begin{array}{c}\text { Kepadatan } \\
\text { per } \mathbf{k m}^{\mathbf{2}}\end{array}$ \\
\hline $\begin{array}{l}\text { Sorong } \\
\text { Barat }\end{array}$ & 254,15 & 35.738 & 140,62 \\
$\begin{array}{l}\text { Sorong } \\
\text { Timur }\end{array}$ & 158,22 & 24.658 & 155,85 \\
\hline
\end{tabular}

\begin{tabular}{lccc}
\hline Sorong & 126,85 & 36.582 & 288,39 \\
Sorong Kep. & 200,10 & 9.395 & 46,95 \\
Sorong & 229,71 & 43.489 & 189,32 \\
Utara & & & \\
Sorong & 135,97 & 32.875 & 241,78 \\
Manoi & & & \\
TOTAL & 1.105 .00 & 182.737 & 165,37
\end{tabular}

\section{Sumber : BPS Kota Sorong}

Berdasarkan data kependudukan pada tabel 1 di atas dan berdasrak kriteria BPS mengenai kelas kota, maka dapat disimpulkan bahwa kota sorong masuk dalam kategori kelas Kota Sedang.

Melihat perkembangan pembangunan di Kota Sorong tersebut, maka kebutuhan tenaga kerja (sumber daya manusia) yang berkualitas diprioritaskan. Dalam upaya meningkatkan kualitas sumber daya manusia, pendidikan mempunyai peranan sangat penting. Salah satu masalah yang bisa menjadi penghalang dalam pembangunan adalah rendahnya kualitas sumber daya manusia. Oleh karena itu pembangunan di sektor pendidikan ditempatkan pada prioritas yang utama. Peningkatan kualitas pada berbagai sector terus dilakukan oleh pemerintah diantaranya penyediaan buku, alat peraga dan alat ketrampilan. Kesejahteraan guru juga harus ditingkatkan secara bertahap.

Jumlah gedung sekolah di Kota Sorong pada tahun ajaran 2008/2009 sebanyak 167 gedung sekolah yang terdiri dari 38 TK, 76 SD, 26 SLTP, 17 SLTA 
Umum dan10 SLTA Kejuruan dan 10 Perguruan Tinggi. Jumlah tenaga pengajar (guru) TK pada tahun ajaran 2008/2009 berjumlah 163 guru dengan 2.816 murid. Ini berarti bahwa setiap guru TK pada Tahun ajaran 2008/2009 memiliki beban mengajar sebanyak 17 murid per satu guru. Di sisi lain, jumlah guru pada jenjang SD terus meningkat jumlahnya. Penambahan jumlah guru SD berbanding lurus dengan bertambahnya jumlah murid SD pada setiap tahun ajaran baru.

Jumlah guru SLTP mengalami kenaikan dari 518 guru pada 2007/ 2008 menjadi 537 guru pada 2008/2009. Penurunan tenaga guru ternyata diikuti oleh penurunan jumlah murid. Terjadi penambahan beban kerja guru dari 17,29 murid per satu guru pada ahun 2007/2008 menjadi 19 murid per satu guru pada tahun 2008/2009. Hal ini disebabkan oleh lebih banyak murid tamatan sekolah dasar yang tidak melanjutkan ke SLTP dibanding dengan penurunan jumlah guru. Pada SLTA Kejuruan, beban kerja guru juga menurun dari 15,43 murid per satu guru pada tahun 2007/2008 menjadi 14 murid per satu guru pada tahun 2008/2009. Akan tetapi pada SLTA umum terjadi peningkatan rasio murid terhadap guru dari 15,16 pada tahun 2007/2008 menjadi 16 pada tahun 2008/2009.
Jumlah Sekolah Negeri dan Sekolah Swasta di Kota Sorong setiap tahun terus bertambah. Walaupun demikian terdapat beberapa persoalan yang sering muncul dalam perkembangan tersebut yakni: a) Terbatasnya kesadaran masyarakat, b) kurangnya fasilitas pendidikan, c) Belum sempurnanya manajemen pendidikan yang ada, d) Terbatasnya tenaga pengajar yang berkualitas, e) Kurangnya koordinasi antar dinas/instansi terkait dalam penanganan masalah pendidikan, f) Terbatasnya dana pendidikan yang ada.

Dengan kata lain, kondisi menurunnya jumlah siswa yang melanjutkan pendidikan ke sekolah menengah disebabkan oleh multifaktor, baik kemampuan ekonomi maupun persepsi dan pemahaman masyarakat tentang manfaat pendidikan.

Pengembangan dan peningkatan kualitas sumber daya manusia dapat dilakukan secara optimal bila terbangun sinergitas antara seluruh komponen pendidikan termasuk masyarakat. Kerja sama dan kesatuan gerak langkah tersebut berawal dari kesadaran, persepsi dan pandangan masyarakat mengenai makna pendidikan sebagai wahana menyiapkan generasi muda untuk mendorong pertumbuhan ekonomi regionalnya. Rumusan think locally act regionally di 
harapkan menjadi maket pengembangan kualitas SDM di Sorong.

Berdasarkan realitas tersebut di atas, sangat penting untuk mengetahui persepsi masyarakat terhadap sistem pendidikan yang ada di Kota Sorong, khususnya pendidikan menengah. Penelitian ini mengungkap bagaimana persepsi masyarakat terhadap pendidikan menengah di Kota Sorong, khususnya di SMAN 2 Kota Sorong.

\section{METODE PENELITIAN}

Pendekatan yang digunakan dalam penelitian ini ialah pendekatan kualitatif dengan menekankan analisis kealamiahan sumber data (Moleong 2001;2). Sementara hasil kajiannya disajikan dengan metode deskriptif yang terdiri atas beberapa tahap, pertama mengumpulkan data, kedua menganalisisnya, dan ketiga menyajikan secara sistematis hasil analisis tersebut. Lokasi Penelitian yaiutu di SMAN 2 Kota Sorong.

Sumber data penelitian ini terdiri atas kata-kata dan tindakan, sumber tertulis, foto, dan data statistik (Moleong, 2001: 112-116). Adapun informan pada peneliatian ini antara lain informan utama (Kepala Sekolah, Komite Sekolah, Guru, Dinas Pendidikan) dan informan bantu (tokoh agama, tokoh masyarakat, perempuan/klpk. Tokoh pemuda, LSM, tokoh adat).
Dalam kegiatan penelitian ini peneliti menjadi instrumen utama dan guna mendukung kegiatan menggunakan instrument bantu seperti; tape recorder, foto toestel, format-format dan alat tulis secukupnya.

Teknik pengumpulan data akan dilakukan dengan menggunakan pengamatan partisipatif, wawancara intensif (deepth interview), diskusi kelompok terarah, dan dilengkapi dengan dokumentasi dalam bentuk gambar-gambar kegiatan. Untuk melengkapi data atau informasi lainnya, dilakukan dengan menggunakan analisis dokumen, sehingga didapatkan data atau informasi dari sumber selain manusia, terutama dokumen-dokumen yang terkait.

Data dianalisis dengan menggunakan metode yang digunakan oleh Bogdan dan Biklen (Moleong, 2001 : 190).

\section{HASIL DAN PEMBAHASAN}

Persepsi Masyarakat tentang Pendidikan Di SMA Negeri 2 Kota Sorong Dalam Kerangka Pelaksanaan Otonomi Khusus Papua

Pendidikan adalah prioritas program otonomi khusus di Papua, termasuk di dalamnya adalah pendidikan menengah. prioritas Otonomi Khusus Papua, yaitu: 1) Pendidikan, 2) Kesehatan, 3) Ekonomi berbasis rakyat, 4) Strategi ketahanan nasional 
Upaya pemerintah dengan berbagai kebijakan di bidang pendidikan juga sangat tergantung pada motivasi masyarakat dalam menentukan pilihan sekolah atau tidak. Apakah pendidikan menengah penting atau tidak, bermanfaat atau tidak akan mempengaruhi perilaku seseorang. Dengan kata lain, apa yang dilakukan seseorang selalu bersumber dari persepsinya terhadap sesuatu dalam menilai diri dan lingkungannya. Seperti apa yang dikatakan Kotler bahwa perilaku bermula dari penginderaan yang ditafsirkan, kemudian muncul perasaan/ emosi yang menimbulkan harapan dan akhirnya menghasilkan tindakan. Persepsi cara seseorang dalam mengolah serta mengartikan informasi yang diperolehnya menjadi sesuatu yang memiliki makna mengenai dunia (Kotler,1992).

\section{Pandangan Masyarakat Tentang Pendidikan Menengah}

Persepsi juga dapat diartikan sebagai pandangan seseorang mengenai informasi yang diperolehnya. Pandangan masyarakat mengenai penyelenggaraan pendidikan di SMA Negeri 2 Kota Sorong mencakup proses pembelajaran, pengelolaan kurikulum, prestasi dan kecukupan sumber daya manusia.

Berdasarkan data wawancara, observasi dan dokumentasi mengenai Pandangan Masyarakat Terhadap
Pelaksanaan Pendidikan di SMAN 2 Kota Sorong, ada beberapa hal yang dapat dirangkum yaitu:

\section{Proses Belajar Mengajar di SMAN 2 Kota Sorong}

Proses belajar-mengajar di SMAN 2 Kota Sorong menggunakan prinsip belajar PAKEM (Pembelajaran Aktif Kreatif Efektif dan Menyenangkan). Proses pembelajaran diupayakan guru berlangsung dalam suasana menyenangkan.

Proses pembelajaran di SMAN 2 Kota Sorong menempatkan siswa sebagai subyek belajar bukan obyek. Karena itu para guru lebih bertindak sebagai motivator dan fasilitator. Para murid (peserta didik) diberi ruang yang cukup fleksibel dalam mengembangkan dirinya. Hal ini menjadi daya tarik bagi para siswa untuk belajar di SMAN 2 Kota Sorong

\section{Alasan/ Motivasi Memilih SMAN 2 Kota Sorong}

Sekolah ini (SMAN 2) memiliki tradisi mutu yang baik. Banyak lulusannya yang diterima di PTN ( banyak siswanya yang diterima di PTN favorit seperti UGM, UI, ITB, ITS dan lain-lain ) dan punya disiplin tinggi.

Hubungan atau interaksi guru dan murid serta hubungan dengan orangtua murid/wali murid yang akrab layaknya orang tua dengan anak-anaknya sehingga 
segala persoalan dapat diselesaikan dengan mudah. Keakraban antar siswa dan guru di SMAN 2 Kota Sorong yang mendasari adalah sikap saling menghormati dan menghargai, sehingga mudah mengembangkan potensi yang ada pada diri siswa, bakat, minat serta kemampuan sehingga mampu menumbuhkan potensipotensi yang terpendam dalam diri siswa.

Belajar di SMAN 2 Kota Sorong suasananya menyenangkan, hampir tidak pernah ada konflik antar siswa, karena kami semua diajarkan untuk saling menghormati dan membantu. Faktor lingkungan sangat memengaruhi semangat belajar siswa (Wael, A., dkk.2018).

Proses pembelajarannya tidak monoton dan penerapan tata tertib sekolah cukup baik dan disiplin. Di sekolah ini jarang ada yang membolos ataupun siswa yang aneh-aneh. Prestasi-prestasi siswa disini cukup baik, apalagi kurikulumnya juga baik. Bagi orang tua/ wali murid, motivasi /alasan memilih SMAN 2 Kota Sorong untuk pendidikan anak adalah: Lokasi : rumah saya sangat dekat dengan sekolah sehingga irit ongkos dan memudahkan pemantauan. Kepercayaan terhadap kemampuan para guru (sebab guru - guru SMAN 2 Kota Sorong selalu berprestasi bahkan belajar ke luar negeri) Kekuatan SMAN 2 Kota Sorong
Kepemimpinan kepala sekolah yang partisipatif, tegas dan mampu memotivasi guru dan siswa; kekompakan para guru, karyawan, komite dan pimpinan; tenaga guru bagaikan taman mini Indonesia berasal dari Sabang-Merauke; lulusannya selalu berprestasi dan mampu bersaing di tingkat nasional dan dunia, mampu merebut tempat di hampir semua PTN di seluruh Indonesia, diterima di fakultas-fakultas yang langka/sulit; kerja sama dengan komite, pemerintah dan masyarakat baik kapabilitas guru tidak diragukan bahkan ada yang sandwich ke luar negeri (Australia)

\section{Catatan yang Perlu diperbaiki}

Menurut para informan, ada beberapa hal yang menjadi kekuatan tetapi beberapa catatan yang perlu diperbaiki, yaitu: Fasilitas laboratorium contoh komputer hanya 40 untuk ribuan siswa; sarana olahraga : yang ada hanya basket, volley dan tenis meja; gedung juga harus direhab (perlu segera direnovasi beberapa bagian dari gedung sekolah, menambah fasilitas, sarana dan prasarana sesuai dengan semakin banyaknya orang yang memilih SMAN 2 Kota Sorong ).

SMAN 2 Kota Sorong sebagai sekolah favorit yang selalu menjadi langganan juara. Wakil Kepala Sekolah mengungkapkan bahwa pada dasarnya KTSP disusun berdasarkan standar isi dan standar 
kompetensi lulusan yang ditunjang oleh kesiapan tenaga pengajar yang memiliki kompetensi profesional, sosial dan personal. Sumber daya manusia di SMA Negeri 2 Kota Sorong Papua Barat terdiri dari 40 guru yang terdiri 38 guru tetap dan 2 guru tidak tetap. Ditinjau dari tingkat pendidikan formalnya, dapat dikatakan bahwa rata rata para guru SMA Negeri 2 Kota Sorong merupakan lulusan program strata satu (S1), bahkan ada yang pascasarjana (S2/S3). Berdasarkan data guru tahun 2013, tampak bahwa sebagian besar para guru di SMA Negeri 2 Kota Sorong yaitu 37 orang atau sekitar $92.5 \%$ merupakan tamatan strata satu (1). Sedangkan $7.5 \%$ merupakan lulusan strata 2 dan 3. Kemudian, sebagian besar merupakan guru tetap yaitu 38 orang (95\%), dan guru tidak tetap 2 orang (5\%).

Komposisi jenjang pendidikan akhir yang dimiliki oleh para guru sangat membantu dalam mengkaji kualitas akademis tenaga pengajar, kuantitas ilmu kependidikan yang diperolehnya sebagai bekal dalam melaksanakan tugas keprofesiannya di SMA Negeri 2 Kota Sorong. Artinya, latar belakang pendidikan menunjukkan bahwa guru tersebut memiliki kapasitas kompetensi dalam pembelajaran, mulai dari menyusun rencana pembelajaran (RPP), pemilihan dan penentuan strategi pembelajaran,media pembelajaran, evaluasi sampai dengan clinic coaching.

Dalam Undang Undang Nomor 14 tahun 2005, tentang Guru dan Dosen, pada Bab I pasal 1 ayat 1 disebutkan: guru adalah tenaga profesional dengan tugas utama mendidik, mengajar, membimbing, mengarahkan, melatih, menilai dan mengevaluasi peserta didik pada pendidikan anak usia dini jalur pendidikan formal, pendidikan dasar dan pendidikan menengah (2006: 3).

Menurut Armstrong dalam bukunya Secondary Erducation (1983: 406) yang menyatakan bahwa terdapat enam fungsi guru yaitu: Guru sebagai instruktur. guru bertanggung jawab dalam menciptakan suasana pembelajaran yang baik dan menyenangkan. Sehubungan dengan itu Armstrong menjelaskan, in planning for instruction, teachers need to master techniques for dealing with six important areas. In our view, successful instructional sequences always involve teacher decision regarding each of the following instructional tasks 1. Diagnosing students' need. 2. Selecting content and establishing objectives. 3. Identifying instructional techniques. 4. Formalizing unit and lesson plans. 5. Motivating students and implementing programs. 6. measuring, 
evaluating, and reporting on student progress.

Guru sebagai Manajer, keberhasilan dalam menjalankan semua unsur tersebut menjadi kunci kesusksesan dalam pendidikan. Guru sebagai Pembimbing, guru hendaknya mengetahui segala sesuatunya yang berhubungan dengan siswanya, guru hendaknya mencari informasi mengenai siswanya baik di dalam lingkungan sekolah maupun di luar sekolah. Salah faktor dari luar individu yang dapat membantu siswa dalam pencapaian tujuan belajar ialah adanya ssstem lingkungan yang kondusif (Kahar, M.S.,dkk, 2018).

Guru sebagai Evaluator, guru hendaknya melakukan evaluasi terhadap proses pembelajaran yang telah dilakukan serta pembinaan yang telah dilakukan kepada siswanya. Semua aspek tersebut dapat berhasil jika dijalankan dengan sungguh-sungguh dan penuh tanggung jawab oleh setiap guru pada setiap sekolah yang ada. Namun selain beberapa hal tersebut, kreatifitas guru-guru sangat diperlukan dalam proses pembelajaran (Balqis Husain, Ibrahim, 2019).

Aspek lain yang harus dikaji juga adalah pengalaman kerja para guru. Kepala Sekolah SMA Negeri 2 merupakan putri asli Papua, yaitu Dra. Elsina Regina Sro"er, MMPd yang menjabat sebagai kepala sekolah sejak tangga 9 Maret 2005 sampai dengan sekarang, atau kurang lebih sudah 8 tahun. Sedangkan mengajar di SMA kurang lebih 21 tahun. Demikian juga berbagai pelatihan yang telah diikuti oleh para guru untuk menunjang proses belajar mengajar, profesionalitas dalam menangani pembelajaran sesuai tuntutan kurikulum, dan peningkatan prestasi siswa.

Berkenaan dengan saran masyarakat dan atau wali murid, Kepala Sekolah dan Wakasek mengungkapkan sisi lain penyelenggaraan pendidikan di SMAN 2 Kota Sorong. Hambatan biaya untuk pengembangan program/ kegiatan dan peningkatan sumber daya guru. Jika alokasi dana pendidikan sebesar $20 \%$ dan dana otsus $30 \%$ direalisasikan dengan baik maka kendala tersebut dapat diatasi.

Kebijakan dana pengembangan pendidikan di Kota Sorong sangat tergantung pada kemauan pemerintah. Dana itu ada, tetapi pemerintah mau atau tidak mendistribusikan sepenuhnya kepada sekolah-sekolah.

Ada perbedaan kebijakan antara kota dan kabupaten. Kepala Sekolah SMAN 2 Kota Sorong dapat melanjutkan pendidikan karena dibantu oleh pemerintah kabupaten, walaupun prestasi sekolah ini mengharumkan Kota Sorong dan SMAN ini 
ada di wilayah kota namun tidak ada perhatian.

Sedangkan sumbangan orang tua murid ditetapkan melalui mekanisme rapat pleno komite sekolah. Dalam rapat komite biasanya disepakati bahwa orang tua murid yang tidak mampu harus dibebaskan dari iuran komite sekolah. Besarnya Anggaran sekolah setiap tahun tertuang dalam RAKS (Rencana Anggaran dan Kegiatan Sekolah) yang diusulkan oleh Kepala Sekolah kepada Komite sekolah dan harus mendapatkan rekomendasi dari Dinas Pendidikan serta penetapan dari Walikota.

Pernyataan pimpinan SMAN 2 Kota Sorong juga diungkapkan dalam wawancara dengan pengawas SMA di Kota Sorong, bahwa pengawas tidak tahu persis berapa jumlah anggaran/bantuan setiap sekolah. Yang pasti bahwa bantuan tersebut bervariasi, tergantung RABS dalam proposal yang diajukan kepada pemerintah. Walaupun tidak selamanya atau tidak semuanya disetujui oleh pemerintah. Demikian pun untuk SMAN 2 Kota Sorong. Pengawas mengakui bahwa tata kelola SMAN 2 sudah bagus. Sebagai contoh, kepala sekolah juga ikut mengampuh mata pelajaran sehingga ketika tim pengawas sekolah mengunjungi SMAN 2 dan kebetulan kepseknya masih mengajar, maka ia tidak akan meninggalkan ruang kelas sampai pelajaran selesai. Jadi kami harus menunggu sampai Kepseknya selesai mengajar. Kepemimipinan manajerial kepala sekolah mempunyai hubungan yang signifikan dan berada pada kategori kuat dengan kinerja guru (Kaharuddin, 2017) Sangat disiplin baik dalam manajemen ketenagaan, akademik maupun administratif. Kepsek SMAN 2 Kota Sorong adalah putrid asli Sorong. Ini merupakan contoh kinerja yang sangat baik.

Menurut Pengawas SMA, penyelenggaraan pendidikan di SMAN 2 Kota Sorong sebenarnya secara konseptual MBS sudah dipahami oleh semua pelaku pendidikan, khususnya para Kepala Sekolah (KS) di Kota Sorong, tetapi implementasinya belum sepenuhnya dilakukan. Dalam MBS pengelolaan diserahkan sepenuhnya kepada sekolah sedangkan pemerintah berperan sebagai fasilitator, dinamisator, dan regulator. Namun demikian ada hal-hal yang menghambat pelaksanaan MBS itu, ialah : (1) Masih adanya campur tangan pemerintah dalam hal pengelolaan SMA/SMK Negeri dan (2) Adanya slogan sekolah gratis sehingga mengendorkan keperdulian peran serta masyarakat.

Menurut Zeinuddin (2008.134-135) Para pengelola pendidikan memiliki tugas antara lain pertama, bagaimana dengan 
sumber pembiayaan pendidikan yang ada dapat melakukan suatu sistem pendidikan yang efesien. Kedua, pengelolaan pendidikan dihadapkan pada usaha menjalin kerjasama dengan berbagai pihak untuk mendapatkan sumber pembiayaan lainnya agar kinerja sekolah dapat lebih ditingkatkan mengingat dana yang ada biasanya dirasa sangat minim walaupun sumbangan orang tua sudah ada. Kerjasama yang perlu dilakukan pengelola pendidikan misalnya dengan para alumni sekolah, perusahaan-perusahaan, lembaga domestik dan ataupun asing. Dukungan pembiayaan tersebut diharapkan dapat digunakan sebagai sumber pendukung pembiayaan pendidikan yang sudah ada. Dengan demikian dapat dikatakan bahwa ada empat sumber dana untuk mendukung pembiayaan dan proses pendidikan, yaitu masyarakat dalam arti orang tua, masyarakat, masyarakat dalam arti pengusaha, pemerintah, dan bantuan dari sumber-sumber luar negeri.

Di SMAN 2 Kota Sorong sumber dana yang ada, paling banyak masih mengandalkan dana pemerintah baik pemerintah pusat dan daerah. Sementara orang tua murid membantu sumbangan yang cukup besar, sedangkan bantuan dari Industri dan perusahaan masih kecil. Padahal bila mencermati profil Sekolah Menengah Atas (SMA) Negeri 2 Kota
Sorong yang terletak di lokasi strategis tepatnya berada di wilayah Distrik Sorong Utara. Mata pencaharian penduduknya adalah Nelayan, Petani, Pegawai, Tukang dan buruh. Karena itu, bantuan pemerintah melalui dana otonomi khusus sangat diharapkan. Apalagi mengingat siswa SMA Negeri 2 Kota Sorong yang berjumlah 961 orang dengan 22 rombel (rombongan belajar). Para siswa ini berasal dari berbagai wilayah distrik di Kota Sorong, walaupun sebagian besar berasal dari Distrik Sorong Utara.

Menurut pimpinan SMAN 2 Kota Sorong, mereka tidak bisa menerapkan bebas SPP murni sebab Komite Sekolah memahami betul kebutuhan sekolah sehingga masih ada beberapa bentuk sumbangan dari wali murid. Ratio penerimaan siswa kami mencoba menyesuaikan dengan kapasitas SDM dan sarana prasarana yang ada sehingga prestasi siswa dan tentunya sekolah dapat dijaga. SMAN 2 mempunyai lebih dari 900 siswa dengan perolehan prestasi bermacammacam. Minat masyarakat sangat tinggi untuk sekolah di SMAN 2 Kota Sorong ,namun diberlakukan seleksi yang ketat dengan menyesuaikan kapasitas ruang dan SDM. Sehingga persentase penerimaan siswa baru setiap tahun tidak lebih dari $69 \%$. Karena itu, para siswa tidak keberatan bila 
ada pungutan dari sekolah, " bapa dan mama bilang tidak apa-apa kalau ada minta sedikit-sedikit dari sekolah sebab itu untuk kualitas siswa juga " (Mrd 01, Juli 2013)

Pada umumnya, siswa SMAN 2 Kota Sorong berasal dari keluarga yang sederhana sebab matapencaharian orang tua mereka sebagai petani. Ke sekolah setiap hari ada yang naik motor, ada banyak yang jalan kaki atau naik angkot. Para siswa optimis dapat lulus pada UAN sebab berdasarkan data kelulusan, SMA Negeri 2 Kota Sorong mampu mencapai tingkat kelulusan di atas $90 \%$ bahkan hampir 100\%. Hal ini sejalan dengan dengan pertimbangan ratio guru dan siswa sejak penerimaan siswa baru. Data tersebut menggambarkan bahwa kualitas pendidikan SMA Negeri 2 Kota Sorong masih diperlukan upaya-upaya peningkatan yang lebih serius, hasil NEM memang menjadi salah satu indikator keberhasilan pendidikan. Namun demikian dalam paradigma baru pendidikan keberhasilan pendidikan tidak semata-mata diukur dari akademik achivement (prestasi akamedik) tetapi yang tidak kalah penting ialah Non Academic Achivement (Prestasi non akademik). Prestasi belajar seharusnya dapat dimaknai secara komprehensif baik dari ranah kognitif, ranah efektif, maupun ranah psikomotorik. Apalagi siswa SMA berada pada tingkat usia dengan karakteristik sendiri. Berdasarkan pembahasan tersebut di atas, ada beberap temuan terkait dengan pandangan masyarakat terhadap penyelenggaraan pendidikan di SMAN 2 Kota Sorong, sebagai berikut :

\section{Temuan 1}

Penyelenggaraan pendidikan di SMAN 2 Kota Sorong mengacu pada peraturan-peraturan yang ada baik standar isi, standar kompetensi lulusan, standar pengawasan, standar Kepala Sekolah, standar kualifikasi akademik dan kompetensi guru, standar pengelolaan pendidikan, standar sarana prasarana, standar proses, dan standar penilaian.

\section{Temuan 2}

Penyelenggaraan pendidikan dan komite sekolah di SMAN 2 Kota Sorong belum berjalan optimal karena dipengaruhi oleh banyak faktor, diantaranya struktur organisasi, kepentingan birokrasi pendidikan, perbedaan penafsiran terhadap peraturan dan pemahaman terhadap konsep MBS.

\section{Temuan 3}

Faktor penentu daya tarik SMAN 2 Kota Sorong adalah: Mutu, banyak lulusannya yang diterima di PTN, disiplin, Pola kepemimpinan kepala sekolah, Prestasi siswa, kemampuan dan kualitas guru, kerja 
sama antara guru, komite sekolah dan pimpinan sekolah, letak/lokasi sekolah (aksesibilitas). Dari temuan 1, 2 dan 3 dirumuskan proposisi sebagai berikut:

\section{Proposisi 1}

Kualitas pembelajaran dan lulusan, pola kepemimpinan, kemampuan guru, kerja sama dan keterjangkauan lokasi sekolah merupakan pembentuk persepsi masyarakat terhadap penyelenggaraan pendidikan menengah.

\section{Latar Belakang Persepsi Masyarakat Terhadap Pendidikan Di SMA Negeri 2 Kota Sorong}

Peningkatan relevansi pendidikan dimaksudkan untuk menghasilkan lulusan yang sesuai dengan tuntutan kebutuhan berbasis potensi sumber daya alam Indonesia. Peningkatan efisiensi manajemen pendidikan dilakukan melalui penerapan manajemen berbasis sekolah dan pembaharuan pengelolaan pendidikan secara terencana, terarah, dan berkesinambungan (Permen No. 22 tahun 2006). Tujuan pendidikan tingkat satuan pendidikan menengah dirumuskan mengacu kepada tujuan umum pendidikan sebagai berikut. 1) Tujuan pendidikan menengah adalah meningkatkan kecerdasan, pengetahuan, kepribadian, akhlak mulia, serta keterampilan untuk hidup mandiri dan mengikuti pendidikan lebih lanjut. 2) Tujuan pendidikan menengah kejuruan adalah meningkatkan kecerdasan, pengetahuan, kepribadian, akhlak mulia, serta keterampilan untuk hidup mandiri dan mengikuti pendidikan lebih lanjut sesuai dengan kejuruannya (BSNP, 2006).

Namun dalam implementasi pendidikan di era Otsus khususnya di SMAN 2 Kota Sorong tidak terlepas dari tipologi masyarakat Sorong khususnya dan Papua pada umumnya. Tipologi berasal dari bahasa Yunani 'tipos' yang secara luas memiliki cakupan makna dalam berbagai variasi dari ide-ide yang sama. Tipologi sering disebut juga dengan istilah tipe. Pengertian tipologi yang dikemukakan oleh Sukada dalam Susilowati (2001:48) merupakan sebuah pengklasifikasian sebuah tipe berdasarkan atas penelusuran terhadap asal-usul terbentuknya objek. Sedangkan tipologi masyarakat dapat diartikan sebagai pengklasifikasian masyarakat ke dalam beberapa tipe atau kelas yang masingmasing kelas tersebut memiliki kesamaan. Tipologi masyarakat atau pembagian masyarakat tersebut dapat mencakup makna yang sangat luas seperti pembagian menurut kondisi sosial ekonomi, menurut adat istiadat, agama dan lainnya.

Pendidikan nasional berfungsi mengembangkan kemampuan dan membentuk watak serta peradaban bangsa yang bermartabat dalam rangka 
mencerdasaskan kehidupan bangsa, bertujuan untuk mengembangkan potensi peserta didik agar menjadi manusia yang beriman dan bertakwa kepada Tuhan Yang Maha Esa, berakhlak mulia, sehat, berilmu, cakap, kreatif, mandiri, dan menjadi warga negara yang demokratis serta bertanggung jawab. Untuk mengemban fungsi tersebut pemerintah menyelenggarakan suatu sistem pendidikan nasional sebagaimana tercantum dalam Undang-Undang Nomor 20 Tahun 2003 tentang Sistem Pendidikan Nasional.

Pendidikan nasional harus mampu menjamin pemerataan kesempatan pendidikan, peningkatan mutu dan relevansi serta efisiensi manajemen pendidikan. Pemerataan kesempatan pendidikan diwujudkan dalam program wajib belajar 9 tahun. Peningkatan mutu pendidikan diarahkan untuk meningkatkan kualitas manusia Indonesia seutuhnya melalui olahhati, olahpikir, olahrasa dan olahraga agar memiliki daya saing dalam menghadapi tantangan global.

\section{SIMPULAN}

Berdasarkan hasil penelitian tersebut, diketahui bahwa persepsi masyarakat terhadap penyelenggaraan pendidikan menengah di SMAN 2 Kota Sorong mengacu pada peraturan-peraturan yang ada baik standar isi, standar kompetensi lulusan, standar pengawasan, standar kepala sekolah, standar kualifikasi akademik dan kompetensi guru, standar pengelolaan pendidikan, standar sarana prasarana, standar proses, dan standar penilaian, Namun penyelenggaraan pendidikan dan komite sekolah di SMAN 2 Kota Sorong belum berjalan optimal karena dipengaruhi oleh banyak faktor, diantaranya struktur organisasi, kepentingan birokrasi pendidikan, perbedaan penafsiran terhadap peraturan dan pemahaman terhadap konsep MBS. Selain itu penyelenggaraan pendidikan di SMAN 2 Kota Sorong ditentukan oleh kualitas pembelajaran, kualitas lulusan, pola kepemimpinan, kemampuan guru, kerja sama dan aksesibilitas.

\section{DAFTAR PUSTAKA}

Abbas, Kasmawati and Zainudin Bin Hassan, 2014. "Integrated Learning Model Cultural-Art And Character Education." e-journal International for Innovation Education and Research Faculty of Education, UTM, Skudai, Johor Bahru. Volume 02-8. (www.ijier.net/index.php/ijier) 
Badan Pusat Statistik (BPS) Kota Sorong, 2009. "Kota Sorong Dalam Angka 2009". Kota Sorong, Papua Barat.

Departemen Pendidikan Nasional. 2005. Undang-Undang Nomor 14 Tahun 2005, Tentang Guru dan Dosen, Jakarta: Depdiknas.

Depdiknas, 2006. Permendiknas No 22 Tahun 2006 Tentang Standar Isi. Jakarta : Depdiknas.

Husain, B. and Ibrahim, I., 2019. Perbedaan Prestasi Belajar Bahasa Inggris Siswa Ditinjau dari Tipe Kepribadian Introvert dan Extrovert. Qalam: Jurnal Ilmu Kependidikan, 7(2), pp.91-106.

Kahar, M.S., Layn, M.R. and Mandasari, I., 2018. Pengaruh Penerapan Model Pembelajaran Interactive Conceptual Interaction (ICI) dalam Pemecahan Masalah Matematika Peserta Didik. Jurnal Noken: Ilmu-Ilmu Sosial, 3(2), pp.56-62.

Wael, A., Asnur, M.N.A. and Ibrahim, I., 2018. Exploring Students' Learning Strategies in Speaking Performance. International Journal of Language Education, 2(1), pp. 65-71.
Kaharuddin, K., 2017. Hubungan Antara Kepemimpinan Manajerial Kepala Sekolah Dengan Kinerja Guru SMA Negeri Kabupaten Bulukumba. Jurnal Noken: Ilmu-Ilmu Sosial, 2(2), pp.2942.

Kotler, 1992. Dasar-Dasar Pemasaran Jakarta: PT Midas Surya Grafindo.

Moleong, Lexy J, 2001.Metodologi Penelitian Kualitatif. Bandung: Remaja Rosdakarya.

Susilowati, Dwi, 2001.” Hubungan Tingkat Pendapatan Dan Pendidikan Orang Tua Dengan Tingkat Pendidikan Anak Dalam Rangka Pengembangan Sumber Daya Manusia Di Desa Tawang Argo Kecamatan Karangploso Kabupaten Malang”, dalam www.itb.centrallibrary.go.id. diakses pada September 2008.

Zamroni,2001.Paradigma Pendidikan Masa Depan Yogyakarta.Yogyakarta : Biagraf Publishing. 